\title{
Effect of Plant-Mediated Synthesized Silver Nanoparticles on Pulse Beetle, Callosobruchus chinensis (L.)
}

\author{
Prem Santhi Yerragopu ${ }^{1 *}$, Sharanagouda Hiregoudar ${ }^{1}$, Udaykumar Nidoni ${ }^{1}$, \\ K. T. Ramappa ${ }^{1}$, A. G. Sreenivas ${ }^{2}$ and S. R. Doddagoudar ${ }^{3}$ \\ ${ }^{1}$ Department of Processing and Food Engineering, College of Agricultural Engineering, \\ University of Agricultural Sciences, Raichur, India \\ ${ }^{5}$ Department of Agricultural Entomology, College of Agriculture, University of Agricultural \\ Sciences, Raichur, India \\ ${ }^{6}$ Department of Seed Science and Technology, College of Agriculture, University of \\ Agricultural Sciences, Raichur- 584 101, Karnataka, India \\ *Corresponding author
}

\section{A B S T R A C T}

Keywords

silver nanoparticles, curry leaves, pulse beetle, soybean, adult mortality

Article Info

Accepted:

20 August 2019

Available Online:

10 September 2019
The present investigation was aimed to study the effect of plant-mediated synthesized silver nanoparticles using curry leaves on pulse beetle, Callosobruchus chinensis (L.) to determine adult mortality, seed damage and seed weight loss. The effect of Ag NPs on pulse beetle, Callosobruchus chinensis (L.) was studied by rearing the insects and preparing bioassay by treating soybean seeds with two concentrations of synthesized and standard Ag NPs (35 and $70 \mathrm{ppm}$ ) at 1:0.3 seed to solution ratio. The adult mortality of $100.00 \%$ was observed in treatment $S_{2} @ 70 \mathrm{ppm}$ on $7^{\text {th }}$ day after treatment and $\mathrm{B}_{2} @ 70 \mathrm{ppm}$ on $14^{\text {th }}$ day after treatment. The minimum seed damage was recorded in treatment $\mathrm{S}_{2}(38.67 \%)$ followed by $\mathrm{B}_{2}(42.00 \%)$ @ $70 \mathrm{ppm}$ and the minimum seed weight loss was recorded in treatment $\mathrm{S}_{2}$ $(0.78 \%)$ followed by $\mathrm{B}_{2}(0.96 \%) @ 70 \mathrm{ppm}$ on $14^{\text {th }}$ day after treatment.

\section{Introduction}

Storage of grains is a part of post-harvest system through which food materials pass from field to consumer. One of the most important and essential issues during storage is the loss in quality and quantity of the grains caused by insects leading to damage and reduction of their dry weight and nutritional value $^{[1]}$. Pulse beetle, Callosobruchus chinensis (L.) is one of the most destructive pests of legumes in storage. It is a severe insect of green gram, pea, cowpea, lentil and has been reported aggressive for soybean, sorghum and maize ${ }^{[2]}$. Its damage generally starts in matured pods in the ground from 
where it is passed to storage space godowns. Both grubs and adults are responsible for causing the harm.

They complete their life cycle in 25-34 days during summer, whereas 40-50 days in winter. They cause 55-60\% loss in the weight of the seed and the seeds become unfit for sowing and even for human consumption ${ }^{[3]}$.

Insect infestation in grains and dry food products is currently controlled by the use of phosphine and methyl bromide, as methyl bromide has been completely phased out all over the world due to its effect on ozone as depletion compound ${ }^{[4]}$. The persistent use of chemicals can lead to serious problems associated with human and environmental health ${ }^{[5]}$.

The carcinogenic potential of the chemical pesticides and its toxic residues on food after application, besides insect's continuous resistance to pesticides are some of the basic problems of this approach.

As a result of this, there is an urgent need to find an alternative for the purpose of insect management that are eco-friendly, safer and economically viable.

Nanotechnology is one of the most novel new approaches for pest management in recent years particularly nanoparticles.

Ag NPs may be an alternative to control growth of insects and pests during storage ${ }^{[6]}$, as they are proved to have potential antibacterial, antifungal and larvicidal properties $^{[7]}$.

Thus, the aim of the present study was to study the effect of biologically synthesized Ag NPs on storage insects in comparison with standard Ag NPs

\section{Materials and Methods}

Biological synthesis of Ag NPs using curry leaves

The biological synthesis of Ag NPs using curry leaves, Murraya koenigii (L.) was arried as per the following procedure.

Ten grams of fresh curry leaves were weighed in an electronic balance were thoroughly rinsed with distilled water and chopped into small pieces using stainless steel knife. The chopped leaves were boiled in $75 \mathrm{~mL}$ of distilled water for $10 \mathrm{~min}$ at $60^{\circ} \mathrm{C}$ using water bath. The leaf extract was cooled to room temperature $\left(25^{\circ} \mathrm{C}\right)$ and filtered using Whatman filter paper No.1 yielding $50 \mathrm{~mL}$ of leaf broth and it was stored in a refrigerator at $8 \pm 1{ }^{\circ} \mathrm{C}$ for further study.

Five $\mathrm{mL}$ of prepared leaf broth was added to $100 \mathrm{~mL}$ of $1.50 \mathrm{mMAgNO}_{3}$ solution ( $1.5 \mathrm{mM}$ was prepared by dissolving $0.0253 \mathrm{~g}$ of $\mathrm{AgNO}_{3}$ in $100 \mathrm{~mL}$ of distilled water). The mixture was incubated at $105^{\circ} \mathrm{C}$ using rectangular hot plate until colour changed from transparent yellow to dark brown indicating the formation of $\mathrm{Ag}$ NPs. The $\mathrm{pH} 9$ of synthesized $\mathrm{Ag}$ NPs was adjusted using $\mathrm{pH}$ meter and stored in a refrigerator $\left(8 \pm 1^{\circ} \mathrm{C}\right)$ for further study[8].

Effect of Ag NPs on pulse beetle, Callosobruchus chinensis (L.) in soybean seeds

The effect of Ag NPs on pulse beetle, Callosobruchus chinensis (L.) was studied by rearing the insects and preparing bioassay by treating soybean seeds with two concentrations of synthesized and standard Ag NPs (35 and $70 \mathrm{ppm}$ ). The detailed procedure followed in carrying out this experiment is presented below. 


\section{Maintenance of pulse beetle culture}

The infested soybean with pulse beetles were procured from Seed Unit, UAS, Raichur and the culture was maintained in a plastic container (size) separately. Initially one kilogram of disinfested soybean seeds were used and adults of $C$. chinensis were released from the infested lot. The plastic containers for maintaining culture were covered with the muslin cloth and fastened with the rubber band. Likewise, the culture was established and continued till they complete two generations. The experiment was conducted at Centre for Nanotechnology, UAS Raichur, maintained at $30 \pm 1^{\circ} \mathrm{C}$ and $75 \pm 5 \%$ relative humidity in continuous dark condition ${ }^{[1]}$.

\section{Bioassay}

The bioassay of pulse beetle was performed with soybean seeds with two different concentrations of Ag NPs in plastic screw capped jars (size $6.00 \times 6.50 \mathrm{~cm}$ ). Fifty grams of fresh soybean seeds, which were free from infestation were weighed using electronic balance and kept in hot air oven for $2 \mathrm{~h}$ at $50 \pm 2^{\circ} \mathrm{C}$ to sterilize and make the sample free from field infestation. Sterilized seeds were primed with both synthesized and standard $\mathrm{Ag}$ NPs at 1:0.3 seed to solution ratio with two concentrations ( 35 and $70 \mathrm{ppm}$ ). Treated seeds were placed in jars and kept for $24 \mathrm{~h}$, then 5 pairs of newly emerged adults were transferred to each box. The experiment was replicated thrice and the untreated seeds were taken as control ${ }^{[9]}$.

\section{Adult mortality}

In each treatment, the number of insects taken was 10 . The number of insects dead from each sample was counted manually and the mean of three replications were taken to calculate the adult mortality ${ }^{[10]}$. Insect mortality was checked after $1^{\text {st }}, 3^{\text {rd }}, 5^{\text {th }}, 7^{\text {th }}$ and $14^{\text {th }}$ day ${ }^{[11]}$.

$$
=\frac{\text { Number of dead insects }}{\text { Total number of insects }} \times 100
$$

\section{Seed damage}

Here, the treated seeds from each treatment $(50 \mathrm{~g})$ were taken and the number of seeds damaged by the insects after $1^{\text {st }}, 3^{\text {rd }}, 5^{\text {th }}, 7^{\text {th }}$ and $14^{\text {th }}$ day were counted ${ }^{[12]}$. The mean of three replications were taken to calculate the seed damage (\%) for each treatment.

Seed damage $(\%)=\frac{\text { Number of damaged seeds }}{\text { Total number of seeds }} \times 100$

\section{Seed weight loss}

The weight of each sample was measured using an electronic balance and replicated thrice. The mean of replications was taken to determine the seed weight loss from each treatment ${ }^{[13]}$.

Seed weight loss $(\%)$
$=\frac{\text { Original weight }(\mathrm{g}) \text { - Final weight }(\mathrm{g})}{\text { Original weight }(\mathrm{g})} \times 100$

\section{Results and Discussion}

\section{Biological synthesis of Ag NPs using curry leaves}

Synthesis of Ag NPs using curry leaves is a green approach and is extensively studied. For this, curry leaf extract was added to $\mathrm{AgNO}_{3}$ solution and a visible colour change from transparent yellow to dark brown was observed, which indicated the formation of $\mathrm{Ag}$ NPs.

This might be due to the reduction of silver ions in the solution by the presence of terpenoids ${ }^{[14]}$. The colour changed from colourless to yellowish and then to dark brown for curry leaves ${ }^{[8,15,16]}$. 
Effect of Ag NPs on pulse beetle, Callosobruchus chinensis (L.) in soybean seeds

The effect of synthesized and standard Ag NPs at two different concentrations against pulse beetle, Callosobruchus chinensis (L.) by considering different entomological parameters such as adult mortality, seed damage and seed weight loss. The results are presented in the following sections and discussed.

\section{Adult mortality (\%)}

\section{$1^{\text {st }}$ day after treatment}

It is evident from Table 1 that, the adult mortality of pulse beetle on day one after treatment recorded a maximum of $6.67 \%$ for $\mathrm{S}_{2} @ 70 \mathrm{ppm}$ which is statistically on par with $\mathrm{B}_{2}(3.33 \%)$. No adult mortality was recorded in the treatments $\mathrm{B}_{1}, \mathrm{~S}_{1} @ 35 \mathrm{ppm}$ and control. It is observed that @70 ppm concentration, all the treatments recorded higher adult mortality compared to $35 \mathrm{ppm}$ of synthesized and standard Ag NPs.

\section{$3^{\text {rd }}$ day after treatment}

The maximum adult mortality of $63.33 \%$ was observed in treatment $S_{2} @ 70$ ppm which was statistically on par with $\mathrm{B}_{2}(50.00 \%) @ 70$ ppm and $\mathrm{S}_{1}(50.00 \%) @ 35 \mathrm{ppm}$. The treatments $\mathrm{B}_{1}(26.67 \%)$ @ $35 \mathrm{ppm}$ recorded minimum mortality. However, there was no mortality in control $(0.00 \%)$.

\section{$5^{\text {th }}$ day after treatment}

It is observed from Table 1 that, the mortality of pulse beetle on $5^{\text {th }}$ day after treatment recorded a maximum of $83.33 \%$ for $\mathrm{S}_{2} @ 70$ ppm, which was followed by $B_{2}, S_{1}$ and $B_{1}$ as 73.33, 70.00 and 53.33, respectively. However, there was no mortality in control $(0.00 \%)$.

\section{$7^{\text {th }}$ day after treatment}

After seven days of treatment the mortality of pulse beetle varied from 76.67 to $100.00 \%$ (Table1). The highest mortality was recorded by standard Ag NPs @ 70 ppm (100.00\%). However, other treatments recorded mortality

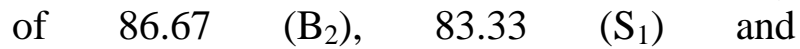
$76.67\left(\mathrm{~B}_{1}\right)$. However, there was no mortality in control $(0.00 \%)$.

It is also observed that @ 70 ppm of Ag NPs, all the treatments recorded higher adult mortality compared to $35 \mathrm{ppm}$ concentration in synthesized and standard Ag NPs.

\section{$14^{\text {th }}$ day after treatment}

The effect of synthesized and standard Ag NPs on adult mortality of pulse beetle on $14^{\text {th }}$ day after treatment is shown in Table 1. The maximum mortality (100.00\%) was observed in treatments $\mathrm{S}_{2} @ 70$ ppm which was statistically on par with all other treatments $\mathrm{B}_{2}$ $(100.00 \%) @ 70$ ppm and $\mathrm{S}_{1}(96.67 \%), \mathrm{B}_{1}$ (93.33\%) @ 35 ppm. However, all the treatments are superior to control (13.33\%).

From the results, it is observed that, with increase in concentrations and number of days after treatment, the adult mortality also increased. Biologically synthesized Ag NPs showed similar effect on adult mortality as standard Ag NPs @ 70 ppm.

Similar results were observed that, the Ag NPs @ 50 ppm showed mortality of $100.00 \%$ on $14^{\text {th }}$ day for adult of Sitophilusoryzae $e^{[1]}$. The Ag NPs @ 50 ppm showed 100.00\% mortality on $4^{\text {th }}$ day after treatment imposition on Sitophilus oryzae ${ }^{[9]} . \mathrm{ZnO}$ NPs @ 1250 ppm recorded mortality of $96.66 \%$ on pulse beetle 10 days after treatment ${ }^{[17]}$. This might be due to ingestion of seed treated with nanoparticles which might have caused abrasion of midgut leading to death of adults ${ }^{[18]}$. 
Table.1 Effect of Ag NPs on pulse beetle, Callosobruchus chinensis in soybean

\begin{tabular}{|c|c|c|c|c|c|c|c|}
\hline \multirow[t]{2}{*}{$\begin{array}{l}\text { Treatment } \\
\text { details }\end{array}$} & \multicolumn{5}{|c|}{$\begin{array}{l}\text { Adult mortality(\%) at different days of } \\
\text { observation* }\end{array}$} & \multirow{2}{*}{$\begin{array}{l}\text { Seed } \\
\text { damage } \\
(\%)\end{array}$} & \multirow{2}{*}{$\begin{array}{l}\text { Weight } \\
\text { loss (\%) }\end{array}$} \\
\hline & 1DAT & 3 DAT & 5 DAT & 7 DAT & 14 DAT & & \\
\hline $\begin{array}{l}\text { Untreated } \\
\text { control }\end{array}$ & $\begin{array}{l}0 \\
(0.00)\end{array}$ & $\begin{array}{l}0 \\
(0.00)\end{array}$ & $\begin{array}{l}0 \\
(0.00)\end{array}$ & $\begin{array}{l}0 \\
(0.00)\end{array}$ & $\begin{array}{l}13.33 \\
(21.13)\end{array}$ & $\begin{array}{l}72.67 \\
(58.54)\end{array}$ & $\begin{array}{l}2.21 \\
(8.54)\end{array}$ \\
\hline B $_{1} @ 35$ ppm & $\begin{array}{l}0 \\
(0.00)\end{array}$ & $\begin{array}{l}26.67 \\
(30.98)\end{array}$ & $\begin{array}{l}53.33 \\
(46.90)\end{array}$ & $\begin{array}{l}76.67 \\
(61.19)\end{array}$ & $\begin{array}{l}93.33 \\
(77.69)\end{array}$ & $\begin{array}{l}56.67 \\
(50.00)\end{array}$ & $\begin{array}{l}1.14 \\
(6.10)\end{array}$ \\
\hline $\mathrm{S}_{1} @ 35$ ppm & $\begin{array}{l}0 \\
(0.00)\end{array}$ & $\begin{array}{l}50 \\
(44.98)\end{array}$ & $\begin{array}{l}70 \\
(56.76)\end{array}$ & $\begin{array}{l}83.33 \\
(66.11)\end{array}$ & $\begin{array}{l}96.67 \\
(83.84)\end{array}$ & $\begin{array}{l}49.33 \\
(44.59)\end{array}$ & $\begin{array}{l}1.06 \\
(5.91)\end{array}$ \\
\hline $\mathbf{B}_{2} @ 70$ ppm & $\begin{array}{l}3.33 \\
(6.14)\end{array}$ & $\begin{array}{l}50 \\
(44.89)\end{array}$ & $\begin{array}{l}73.33 \\
(58.98)\end{array}$ & $\begin{array}{l}86.67 \\
(68.82)\end{array}$ & $\begin{array}{l}100 \\
(90)\end{array}$ & $\begin{array}{l}42 \\
(40.37)\end{array}$ & $\begin{array}{l}0.96 \\
(5.61)\end{array}$ \\
\hline$S_{2} @ 70$ ppm & $\begin{array}{l}6.67 \\
(12.28)\end{array}$ & $\begin{array}{l}63.33 \\
(52.75)\end{array}$ & $\begin{array}{l}83.33 \\
(66.11)\end{array}$ & $\begin{array}{l}100 \\
(90)\end{array}$ & $\begin{array}{l}100 \\
(90)\end{array}$ & $\begin{array}{l}38.67 \\
(38.42)\end{array}$ & $\begin{array}{l}0.78 \\
(5.07)\end{array}$ \\
\hline Mean & 2 & 38 & 55.99 & 69.33 & 80.66 & 51.86 & 1.23 \\
\hline $\operatorname{SEm}( \pm)$ & 2.10 & 5.57 & 2.58 & 2.58 & 2.58 & 2.93 & 0.09 \\
\hline C.D.@1\% & 6.42 & 17.83 & 8.24 & 8.24 & 8.24 & 9.37 & 0.30 \\
\hline
\end{tabular}

Note: DAT- Days After Treatment

*Average of 5 pairs

Figures in the parentheses are angular transformed values

Fig. 1 Effect of Ag NPs on adult mortality (\%) of pulse beetle in soybean

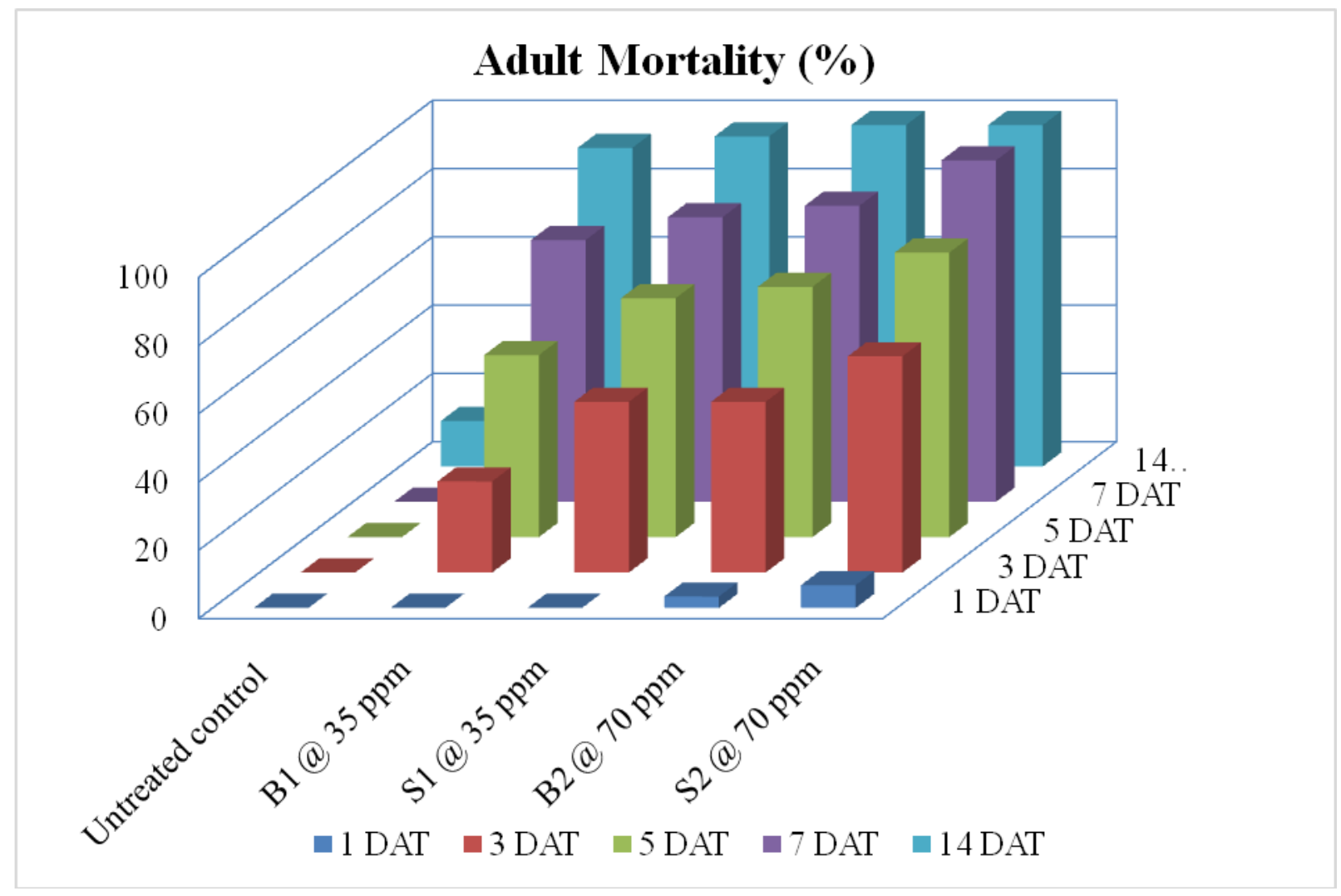




\section{Seed damage $(\%)$}

The effect of different treatments on seed damage was recorded on $14^{\text {th }}$ day after treatment. Among all the treatments, the minimum seed damage was recorded in treatment $\mathrm{S}_{2}(38.67 \%) @ 70 \mathrm{ppm}$ and maximum seed damage was observed in $\mathrm{B}_{1}$ (56.67\%)@35 ppm. Treatment $\mathrm{S}_{2} @ 70$ ppmwas statistically on par with the treatments $\mathrm{B}_{2}(42.00 \%) @ 70 \mathrm{ppm}$ and all the treatments are superior to control $(72.67 \%)$. It is also observed that Ag NPs @ 70 ppm of all the synthesis methods showed lower seed damage as compared to Ag NPs @ 35 ppm and control (Table 1).

Application of synthesized and standard Ag NPs resulted in reduced seed damage potential in all the treatments over control. It is observed that biologically synthesized Ag NPs showed similar effect on reduction of seed damage as standard Ag NPs @ 70 ppm. The per cent seed damage was reduced (4\%) for wheat grain using Ag NPs (200 ppm) treatment over control ${ }^{[19]}$. ZnO NPs @ 1000 ppm reduced the seed damage by $75 \%$ over the control ${ }^{[17]}$. The reduction in seed damage by the infestation of pulse beetle Callosobruchus chinensis (L.) treated with silica nanoparticles ${ }^{[18]}$. There was inverse relationship between adult mortality (\%) and seed damage $(\%)$.

\section{Seed weight loss (\%)}

From Table 1 it is observed that, the treatment $\mathrm{S}_{2} @ 70 \mathrm{ppm}$ was found to have minimum seed weight loss $(0.78 \%)$ and the maximum seed weight loss was observed in $\mathrm{B}_{1}(1.14 \%)$ @ $35 \mathrm{ppm}$. Treatment $\mathrm{S}_{2}$ @ $70 \mathrm{ppm}$ was statistically on par with $\mathrm{B}_{2}(0.96 \%)$ and $\mathrm{S}_{1}$ $(1.06 \%)$. All the treatments are superior to control $(2.21 \%)$.

Reduced seed weight loss was observed due to application of $\mathrm{Ag}$ NPs at two different concentrations compared to control. For silica nanoparticles at $1000 \mathrm{ppm}$ in pulse beetle, Callosobruchus chinensis (L. ${ }^{[18]}$.The reason for reduction in seed weight loss (\%) and seed damage (\%) might be due to early mortality of pulse beetles.

Biological synthesis of Ag NPs was carried out by using curry leaves, Murraya koenigii (L.) as reducing agent. Formation of Ag NPs was confirmed by the colour change from transparent yellow to dark brown. Theeffect of synthesized and standard Ag NPs on pulse beetle, Callosobruchus chinensis (L.) in soybean seed by priming method @ (1.00:0.30 seed to solution ratio) by considering different entomological parameters. The adult mortality of $100.00 \%$ was observed in treatment $S_{2} @$ $70 \mathrm{ppm}$ on $7^{\text {th }}$ day after treatment and $\mathrm{B}_{2} @ 70$ ppm on $14^{\text {th }}$ day after treatment. The minimum seed damage was recorded in treatment $\mathrm{S}_{2}$ (38.67\%) followed by $\mathrm{B}_{2}(42.00 \%) @ 70$ ppm and the minimum seed weight loss was recorded in treatment $\mathrm{S}_{2}(0.78 \%)$ followed by $\mathrm{B}_{2}(0.96 \%) @ 70 \mathrm{ppm}$ on $14^{\text {th }}$ day after treatment. Hence, it was found that biologically synthesized Ag NPs showed better entomological parameters @ $70 \mathrm{ppm}$ and recorded almost similar results as standard Ag NPs @ 70 ppm.

\section{Acknowledgement}

The authors gratefully acknowledge the Senior Research Fellowship (SRF) sponsored by Indian Council of Agricultural Research (ICAR), Govt. of India.

\section{References}

Zahir, A, A., Bagavan, A., Kamaraj, C., Elango, G. and Rahuman, A., 2012, Efficacy of plant-mediated synthesized silver nanoparticles against Sitophilus oryzae. Journal of Biopesticides, 5(2): 
95-102.

Ahmed, K. S., Itino, T. and Ichikawa, T., 2003, Duration of developmental stages of Callosobruchus chinensis (Coleoptera: Bruchidae) on Adzuki bean and the effects ofneem and sesame oils at different stages of their development. Pakistan Journal of Biological Sciences, 6(10): 932-335.

Gujar, G. T. and Yadav, T.D., 1978, Feeding of Callosobruchus maculatus (Fab.) and Callosobruchus chinensis. in green gram. Indian Journal of Entomology, 40(1): 108-112.

Sparks, D., Dripps, T. C., Watson, J. E. and Paroonagian, G. B., 2012, Resistance and cross resistance to the spinosynsAre view and analysis. PesticideBiochemistry and Physiology, 102(1): 1-10.

Ragaei, M. and Sabry, A. H., 2014, Nanotechnology for insect pest control. International Journal of Science and Technology, 3(2): 22783687.

Al-Othman, M. R., El-Aziz, A. R. M., Mahmoud, M. A., Eifan, S. A., ElShikh, M. S. and Majrashi, M., 2014, Application of silver nanoparticles as anti-fungal and anti-aflotoxin $\mathrm{B}_{1}$ produced by Aspergillus flavus. Digest Journal of Nanomaterials and Biostructures, 9(1): 151-157.

Saxena, A. P., Tripathi, R. M. and Singh, R. P.,2010, Biological synthesis of silver nanoparticles using onion (Allium cepa) extract and their antibacterial activity. Digital Journal of Nanomater Bioscience, 5(2):427432.

Christensen, L., Vivekanandhan, S., Misra, M. and Mohanty, A. K., 2011, Biosynthesis of silver nanoparticles using Murraya koenigii (curry leaf): An investigation on the effect of broth concentration in reduction mechanism and particle size. Advanced Materials Letter, 2(6): 429-434.

Sankar, M. V. and Abideen, S., 2015, Pesticidal effect of green synthesized silver and lead nanoparticles using Avicennia marina against grain storage pest Sitophilus oryzae. International Journal of Nanomaterials and Biostructures, 5(3): 32-39.

Rouhani, M., Samih, M. A. and Kalantri, S., 2012, Insecticidal effect of silica and silver nanoparticles on the cowpea seed beetle, Callosobruchus maculatus F. (Col.: Bruchidae). Journal of Entomology Research, 4(4): 297-305.

Debnath, N., Das, S. and Seth, D., 2011, Entomotoxic effect of silica nanoparticles against Sitophilus oryzae (L.). Journal of Pest Sciences, 84(1): 99-105.

Tamiru, A., Bayih, T. and Chimdessa, M., 2016, Synergistic bioefficacy of botanical insecticides against Zabrotes Subfasciatus (Coleoptera:bruchidae) a major storage pest of common bean. Journal of Fertile Pesticides, 7(2): 1-8.

Harris, K. L. and Lindblad, C. J., 1978, A manual of methods for the evaluation of post-harvest losses. American Association of Cereal Chemists, 8(2): 75-79.

Sajeshkumar, N. K., Vazhacharickal, P. J., Mathew, J. J. and Sebastin, A., 2015, Synthesis of silver nano particles from curry leaf (Murraya koenigii) extract and its antibacterial activity. Journal of Pharmaceutical Sciences, 4(2): 95102.

Ashtaputrey, S. D., Ashtaputrey, P. D. and Rathod, G., 2017, Eco-friendly green synthesis and characterization of silver nanoparticles derived from Murraya koenigii leaves extract. Asian Journal of Chemistry, 29(9): 1966-1968.

Raju, N. K. and Ebency, C. I. L., 2017, 
Biosynthesis of silver nanoparticles from Murraya koenigii and its application in effluent treatment. European Journal of Pharmaceutical and Medical Research, 4(7): 514-518.

Wazid, Nadagouda, S., Prabhuraj, A.,Naik, R. H.,Shakuntala, N. M. and Sharanagouda, H., 2018, Effect of biosynthesized zinc oxide green nanoparticles on pulse beetle, Callosobruchus analis (Coleoptera: Chrysomelidae). International Journal of Current Microbiology and Applied Sciences, 7(9): 503-512.

Arumugam, G., Velayutham, V., Shanmugavel, S. and Sundaram, J.,
2016, Efficacy of nanostructured silica as a stored pulse protector against the infestation of bruchid beetle,Callosobruchus maculatus (Coleoptera: Bruchidae).Applied Nanoscience, 6(3): 445-450.

Saleem, Abeer, Salam, A. E., Hamzah, A. M., Nariman, M. and Taweelah, E., 2015, Aluminum and zinc oxides nanoparticles as a new method in controlling the red flour beetle,Tribolium castaneum (Herbest) compared to malathion insecticide. International Journal of Scientific Research in Agricultural Sciences, 2(5): 1-6.

\section{How to cite this article:}

Prem Santhi Yerragopu, Sharanagouda Hiregoudar, Udaykumar Nidoni, K. T. Ramappa, A. G. Sreenivas and Doddagoudar, S. R. 2019. Effect of Plant-Mediated Synthesized Silver Nanoparticles on Pulse Beetle, Callosobruchus chinensis (L.). Int.J.Curr.Microbiol.App.Sci. 8(09): 1965-1972. doi: https://doi.org/10.20546/ijcmas.2019.809.227 